\title{
JANUARY EFFECT DAN SIZE EFFECT \\ PADA PERUSAHAAN YANG TERDAFTAR DI BURSA EFEK INDONESIA.
}

\author{
Aulia Rahma Yani \\ Universitas Brawijaya \\ (No. Telp 085748496707)
}

Made Sudarma

Yeney Widya Prihatiningtias

(Program Pascasarjana Fakultas Ekonomi dan Bisnis Universitas Brawijaya)

\begin{abstract}
Capital market is called efficient if the prices in the market reflect all the information that may be obtained by investors. In the efficient market there is no possibility to obtain abnormal returns, although in practice there are things that are deviant, called anomalies. This study aims to examine and analyze the existence of the January Effect and Size Effect on stock returns in the Indonesia Stock Exchange (BEI) in 2007-2012. The method used is to test whether there are differences in the value of Average Abnormal Return (AAR) before and after January 1, to investigate the January effect, and statistical tests used independent T-test. While to examine whether there is the Effect Size see whether differences Average Cumulative Abnormal Return (ACAR) between small capitalization stocks with large capitalization stocks in January and statistical tests used paired T-test. The results of this study prove that there is no January Effect and Size Effect on test periods.
\end{abstract}

Keywords: January Effect, Effect Size, Average Abnormal Return, Cumulative Average Abnormal Return

\begin{abstract}
Abstrak
Pasar modal disebut efisien bila harga-harga dalam pasar tersebut mencerminkan semua informasi yang mungkin diperoleh investor. Pada pasar yang efisien tidak ada kemungkinan memperoleh tingkat pengembalian abnormal, meskipun dalam prakteknya terdapat hal-hal yang menyimpang, yang disebut anomali. Penelitian ini bertujuan untuk menguji dan menganalisis adanya eksistensi January Effect dan Size Effect pada return saham di Bursa Efek Indonesia (BEI) tahun 2007-2012.Metode penelitian yang digunakan adalah dengan menguji apakah terdapat perbedaan nilai Average Abnormal Return (AAR) sebelum dan sesudah tanggal 1 Januari untuk mengetahui adanya January Effect, dan tes secara statistik digunakan Uji-T
\end{abstract}


independen. Sedangkan untuk menguji apakah terdapat Size Effect adalah dengan melihat apakah perbedaan Average Cumulative Abnormal Return (ACAR) antara saham kapitalisasi kecil dengan saham kapitalisasi besar pada Bulan Januari dan tes secara statistik digunakan Uji-T berpasangan. Hasil dari penelitian ini membuktikan bahwa tidak terjadi January Effect dan Size Effect pada periode uji.

Kata Kunci: January Effect, Size Effect, Abnormal Return, Average Abnormal Return, Average Cumulative Abnormal Return

\section{PENDAHULUAN}

Pasar modal merupakan suatu sarana penting dalam perekonomian yang berfungsi memobilisasi dana dari masyarakat ke sektor produktif. Perusahaan sebagai pihak yang membutuhkan dana dapat menghimpun dana melalui pasar modal dengan menjual sahamnya kepada publik atau menerbitkan surat utang, sedangkan investor sebagai pihak yang memiliki dana dapat mempergunakan pasar modal sebagai salah satu alternatif investasi guna memperoleh keuntungan.

Dalam pemilihan dan pembentukan portofolio saham, manajer investasi dan investor membutuhkan informasi-informasi mengenai kondisi atau arah pergerakan pasar untuk menilai resiko yang melekat dalam investasinya dan juga untuk memperkirakan return yang diperoleh dari investasi tersebut. Dengan informasi yang diperoleh, investor dapat membuat suatu keputusan dan menentukan posisi jual, beli atau menahan suatu saham.

Di pasar yang efisien, pasar akan cepat bereaksi terhadap informasi baru yang masuk sehingga pasar akan dengan cepat pula mencapai harga keseimbangan yang baru. Pada pasar yang efisien tidak ada kemungkinan memperoleh tingkat pengembalian abnormal, meskipun dalam prakteknya terdapat hal-hal yang menyimpang, yang disebut anomali. Beberapa penelitian pada bursa efek dinegara maju (Amerika Serikat) terdapat beberapa fenomena ketidakberaturan (anomali) yang tidak sejalan dengan kondisi pasar modal yang efisien. Anomali-anomali tersebut dalam Elton dan Gruber (1995) diantaranya adalahSize Effect dan January Effect

Penelitian ini ingin melihat apakah January Effect dan Size Effect juga berdampak yang sama dengan apa yang terjadi pada pasar modal kawasan Amerika dan negara Asia lainnya. Hal inilah yang menjadi alasan mengapa penelitian ini dilakukan. Terlebih dengan adanya penelitian serupa yang telah dilakukan di Indonesia menunjukkan hasil yang berbeda-beda. 


\section{TINJAUAN PUSTAKA}

\section{Konsep Pasar Modal Yang Efisien}

Konsep tersebut menyiratkan adanya suatu proses penyesuaian harga sekurits menuju harga keseimbangan yang baru, sebagai respon atas informasi baru yang masuk ke pasar. Pada waktu tertentu, pasar bisa overadjusted atau underadjusted ketika bereaksi terhadap informasi baru, sehingga harga baru yang terbentuk bisa jadi bukan merupakan harga yang mencerminkan nilai intrinsik dari sekuritas tersebut. Meskipun proses penyesuaian harga tidak harus berjalan dengan sempurna, tetapi yang terpenting dalam mekanisme pasar efisien adalah harga yang terbentuk tidak bias dengan estimasi harga keseimbangan (Christianto, 2010).

Beberapa kondisi yang harus dipenuhi untuk tercapainya pasar yang efisien, yaitu (Tendelin, 2001):

a. Ada banyak investor yang rasional dan berusaha untuk memaksimalkan profit. Investorinvestor tersebut secara aktif berpartisipasi di pasar dengan menganalisis, menilai dan melakukan perdagangan saham. Tindakan dari satu investor tidak akan mampu mempengaruhi harga dari sekuritas.

b. Semua pelaku pasar dapat memperoleh informasi pada saat yang sama dengan cara yang murah dan mudah.

c. Informasi yang terjadi bersifat random.

d. Investor bereaksi secara cepat terhadap informasi baru, sehingga harga sekuritas akan berubah sesuai dengan perubahan nilai sebenarnya akibat informasi tersebut.

\section{Anomali Pada Efisiensi Pasar Modal}

Dari penelitian Pratomo (2007) dapat ditunjukkan adanya suatu ketidakteraturan yang terdeteksi dalam pasar modal yang tidak sesuai dengan apa yang diharapkan dari hipotesis efisiensi pasar modal. Ketidakteraturan ini berlangsung terus menerus dan memiliki dampak yang cukup luas sehingga disebut sebagai suatu anomali pasar (market anomalies). Anomali disini adalah suatu bentuk fenomena yang ada di pasar. Pada anomali ditemukan hal-hal yang seharusnya tidak ada bilamana dianggap bahwa pasar efisien benar-benar ada. Artinya, suatu peristiwa dapat dimanfaatkan untuk memperoleh abnormal return. Dengan kata lain, dimungkinkan seorang investor untuk memperoleh abnormal return dengan mengandalkan suatu peristiwa tertentu (Gumanti dan Utami, 2002). 
Namun demikian, hingga saat ini belum ada penjelasan yang memuaskan mengenai terjadinya anomali pasar di suatu pasar modal negara tertentu tetapi tidak terjadi di pasar modal negara lain. Beberapa anomali-anomali empiris yang bertentangan dengan teori pasar efisien adalah sebagai berikut:

\section{January Effect}

January Effect adalah kecenderungan naiknya harga saham antara tanggal 31 Desember sampai dengan akhir minggu pertama pada Bulan Januari. Chatterjee (2000) menemukan adanya January Effect yang signifikan dari return perusahaan kecil dibandingkan dengan perusahaan besar yang terjadi pada beberapa hari pertama di Bulan Januari. Munculnya January Effect antara lain dikarenakan adanya hipotesis taxloss selling, windowdressing, dan small Stock's Beta (Sharpe, 1995).

\section{a. Tax Loss Selling}

Penjelasan paling populer berkaitan dengan January Effect adalah hipotesistax-loss selling dimana investor menjual saham yang nilainya turun. Hal inidimaksudkan untuk menghasilkan tax loss sebelum akhir tahun atau mengurangijumlah pajak yang ditanggungnya(Chotigeat dan Pandey, 2005).

\section{b. Window Dressing}

Window dressing yaitu terjadinya aksi jual pada saham-saham yangmemiliki kinerja buruk di akhir tahun. Window dressing ini tidak jauh berbedadengantax loss selling, dimana hal ini dilakukan oleh manajerkeuangan dengan tujuan agar laporan kinerjaportofolio saham yangdilaporkannya pada akhir tahun akan tampak bagus kinerjanya (Sharpe, 1995).Investor institusional menjual saham yang dianggap buruk menjelang akhir tahununtuk memperbaiki portofolio akhir tahun mereka kemudian mereka dan membeliulang saham-saham tesebut. Aksi jual di akhir tahun ini akan mengakibatkanturunnya harga saham tersebut di akhir tahun dan harga akan berangsur normalkembali di Bulan Januari setelah berakhirnya aksi jual tersebut. Window Dressingini terutama dilakukan oleh investor institusional yang mengakibatkan returnsaham yang tinggi di bulan Januari (Pratomo, 2000).

\section{c. Small Stock's Beta}

Saham dengan kapitalisasi pasar kecil memiliki resiko yang lebih besarpada Bulan Januari daripada pada bulan-bulan lainnya. Bila hal tersebut benarmaka saham kapitalisasi kecil tersebut akan memiliki rata-rata return yang relatif lebih tinggi pada Bulan Januari dibandingkan dengan 
bulan-bulan lainnya dan terdapat hubungan yangpositif antara saham perusahaan kecil dan beta saham tersebut terhadap abnormalreturn (Sharpe, 1995).

\section{Size Effect}

Kapitalisasi pasar diperoleh dari perkalian antara harga saham penutupan dengan jumlah saham yang diterbitkan (Ang, 2000). Saham-saham yang diperdagangkan di Bursa Efek Indonesia sendiri dapat dibagi atas kelompok berdasarkan kapitalisasi pasar, yaitu kapitalisasi besar (Big-Cap), kapitalisasi sedang (Mid-Cap) dan kapitalisasikecil (Small-Cap).

Saham yang berkapitalisasi besar ini merupakan saham yang nilai kapitalisasi pasarnya lebih besar atau sama dengan 5 triliun rupiah (Ang, 2000). Saham ini disebut juga saham papan atas. Saham kelompok ini kebanyakan menjadi incaran investor untuk investasi jangka panjang karena resiko yang relatif rendah. Saham yang berkapitalisasi sedang memiliki kapitalisasi pasar antara 1 triliun sampai dengan 5 triliun rupiah. Saham kelompok ini memberikan daya tarik tersendiri bagi investor karena di samping return on investment yang relatif besar harga juga harga saham umumnya cenderung stabil atau naik.

Sedangkan saham dengan kapitalisasi pasar kecilyaitu saham-saham yang memiliki nilai kapitalisasi pasar di bawah 1 triliun rupiah. Saham ini menghasilkan return on investment yang tinggi karena harganya yang relatif murah, namun demikian diiringi oleh resiko yang besar berupa kerugian (Ang, 2000). Pengertian Size Effect adalah bahwa saham-saham dengan kapitalisasi pasar kecil (small firm) cenderung menghasilkan return yang lebih tinggi dibandingkan saham dengan kapitalisasi pasar yang besar.

\section{Harga Saham}

Menurut Belkoui (2002) harga saham adalah nilai dari pernyataan dan kepemilikan seseorang dalam suatu perusahaan. Harga saham yang terjadi pada pasar modal efisien merupakan refleksi dari semua informasi yang telah dipublikasikan dan terjadi pada keseimbangan yang berkelanjutan.Hal ini berarti bahwa harga saham tersebut adalah sama dengan nilai intrinsic dari saham tersebut di setiap waktu.

\section{Abnormal Return}

Abnormal return atau exces return merupakan kelebihan dari return yang sesungguhnya terjadi terhadap return normal (Jogiyanto, 2003). Return normal merupakan return ekspektasi 
(return yang diharapkan oleh investor). Dengan demikian abnormal return adalah selisih antara return sesungguhnya yang terjadi dengan return ekspektasi.

Return sesungguhnya merupakan return yang terjadi pada waktu ke-t yang merupakan selisih harga sekarang relatif terhadap harga sebelumnya. Sedang return ekspektasi merupakan return yang harus diestimasi. Jogiyanto (2003) mengestimasireturn ekspektasi mengguanakan model estimasi mean-adjusted model, market modeldan market adjusted model. Dalam penelitian ini abnormal return yang dipakai adalah abnormal return yang meggunakan model estimasi market adjusted model. Hal ini dikarenakan Market adjusted model menganggap bahwa penduga yang terbaik untuk mengestimasireturn suatu sekuritas adalah return indeks pasar pada saat tersebut.

\section{Hipotesis}

Berdasarkan kajian teori dan penelitian terdahulu, maka dapat dirumuskan hipotesis pertama sebagai berikut:

H1: Terdapat perbedaan nilai Average Abnormal Return (AAR) sebelum dan sesudah tanggal 1 Januari.

Nilai Average Cumulative Abnormal Return (ACAR) digunakan untuk mengetahui adanya Size Effect, yaitu dengan membandingkan nilai ACAR saham kapitalisasi besar dengan saham kapitalisasi kecil,dimana hasil dari perbandingan tersebutdapat diketahui apakah benar saham perusahaan dengan kapitalisasi kecil mempunyai return yang lebih tinggi dibandingkan saham kapitalisasi besar selama bulan Januari.Berdasarkan kajian teori dan penelitian terdahulu, maka dapat dirumuskan hipotesis kedua dalam penelitian ini, yaitu:

H2: Terdapat perbedaan Average Cumulative Abnormal Return (ACAR) antara saham kapitalisasi kecil dengan saham kapitalisasi besar pada Bulan Januari.

\section{METODE PENELITIAN}

\section{Jenis Dan Sumber Data Penelitian}

Populasi yang diambil untuk penelitian ini adalah semua perusahaan yang terdaftardi BEI dari periode 2007 sampai dengan 2012. Sedangkan sampel dalam penelitian ini adalah sahamsaham yang terdaftar di BEI pada sektor perbakan, properti, dan infrasturktur selama periode 
2007-2012.Ketiga sektortersebut dipilih karena bisa dikatakan paling laku untuk diakumulasi beli (Binarto, 2013).

Event windows dalam penelitian ini menggunakan event windows 7 hari (3 hari sebelum dan 3 hari sesudah tanggal 1 Januari), dengan alasan keberadaan anomali January Effect dan Size Effect dapat dengan mudah menjadi perhatian para investor. Sehingga, periode event windows tersebut dipilih karena investor dapat bereaksi dengan cepat dan menghindari informasi lain yang masuk (Jogiyanto, 2000). Periode dalam penelitian ini dilakukan selama tahun 2007-2012, dengan periode penelitian selama 6 tahun terakhir (2007-2012), diharapkan penelitian ini dapat memberikan hasil lebih kini dan akurat. Periode pengamatan digambarkan sebagai berikut:

\section{Gambar Periode pengamatan 7 hari}

$\begin{array}{lllllll}-3 & -2 & -1 & 0 & +1 & +2 & +3\end{array}$

\section{Variabel Penelitian}

\section{Definisi Operasional Variabel}

Dalam penelitian ini, yang menjadi variabelpenelitian adalah abnormal return. Abnormal return merupakan kelebihan dari return yang sesungguhnya terjadi terhadap return normal (Jogiyanto, 2003). Return normal merupakan return ekspektasi (return yang diharapkan oleh investor). Dengan demikian, abnormal return dihitung dari selisih antara return yang sesungguhnya terjadi dengan return ekspektasi.

Kemudian, dari hasil perhitungan abnormal return harian dicari nilai Average Abnormal Return (AAR). Dari hasil perhitungan nilai AAR tersebut dapat dilakukan pengujian untuk mengetahui adanya January Effect. Selanjutnya, untuk mengetahui adanya Size Effect, digunakan nilai Cumulative Average Abnormal Return (ACAR) dari masing-masing periode (tiap tahun). Dari hasil pengukuran tersebut dapat dilihat apakah terdapat Size Effect pada periode penelitian.

\section{Pengukuran Variabel}

\section{Abnormal Return}

Penelitian ini menggunakan pengukuran abnormal return dengan metode market adjusted return. Sehingga nilai abnormal return saham dapat dihitung dengan cara:

$$
\mathrm{AR}_{\mathrm{it}}=\mathrm{R}_{\mathrm{i}, \mathrm{t}}-\mathrm{R}_{\mathrm{mt}}
$$




\section{Cumulative Abnormal Return (CAR)}

Selanjutnya adalah menghitung Cumulative Abnormal Return (CAR), CAR merupakan penjumlahan abnormal return selama periode peristiwa untuk masing-masing sekuritas, yang dihitung sebagai berikut:

$$
\mathrm{CAR}_{\mathrm{t}} \quad=\quad{ }_{\mathrm{t}-\mathrm{n}} \sum^{\mathrm{K}} \mathrm{AR}_{\mathrm{i}, \mathrm{t}}
$$

\section{Average Abnormal Return (AAR)}

Kemudian dicari Average Abnormal Return (AAR) yang digunakan untuk lebih mengonsentrasikan nilai abnormal return dari semua perusahaan. Dalam penelitian ini AAR dihitung dengan rumus:

$$
\mathrm{AAR}_{\mathrm{t}}=\mathrm{K}^{\mathrm{t}-\mathrm{n} \sum^{\mathrm{K}} \mathrm{AR}_{\mathrm{i}, \mathrm{t}}}
$$

\section{Average Cumulative Abnormal Return (ACAR)}

Berikutnya adalah menghitung Average Cumulative Abnormal Return (ACAR). ACAR diperoleh dari menghitung rata-rata nilai CAR dari setiap observasi yang dilakukan. Perhitungan ACAR dapat dirumuskan:

$\operatorname{ACAR}_{\mathrm{t}} \quad=\underline{\mathrm{t}-\mathrm{n} \sum{ }^{\mathrm{K}} \mathrm{CAR}_{\mathrm{i}, \mathrm{t}}}$

\section{$\mathrm{K}$}

\section{Uji Normalitas}

Uji normalitas bertujuan untuk menguji apakah data memiliki distribusi normal (Sucipto, 2012). Uji normalitas pada dasarnya dilakukan untk membandingkan antara data yang dimiliki dengan data berdistribusi normal yang memiliki mean dan standar deviasi yang sama. Data yang mempunyai distribusi normal merupakan syarat dilakukannya parametric-test dan berarti mempunyai sebaran yang normal pula, sehingga data tersebut dianggap bisa mewakili populasi.

Untuk menguji apakah sampel penelitian berdistribusi normal, maka digunakan pengujian Kolmogorov Smirnov Test terhadap masing-masing variabel dengan $\alpha=$ 5\%.Hipotesispengujianyaitu:

H0: Data menyebar normal

H1: Data tidak menyebar normal

Dengan ketentuan jika $p$-value $<\alpha$ maka tolak H0 dan sebaliknya, jika $p$-value $>\alpha$ maka terima H0 


\section{PENGUJIAN HIPOTESIS}

\section{Pengujian Hipotesis 1}

Pengujian statistik dalam penelitian ini menggunakan Uji-t independen. Sebelum melakukan uji signifikansi t independen, maka perlu dilakukan pengujian kehomogenan ragam 2 sampel tersebut. Pengujian digunakan untuk mengetahui apakah 2 sampel tersebut memiliki ragam yang homogen (konstan) atau tidak.

Untuk menguji apakah 2 sampel penelitian memiliki ragam yang homogen, maka digunakan pengujian rasio 2 ragam terhadap masing-masing sampel dengan $\alpha=5 \%$.

Kriteria pengujian menyatakan jika probabilitas hitung >level of significance $(\alpha)$ maka 2 sampel tersebut dikatakan memiliki ragam yang homogen.Hipotesispengujianyaitu:

H0: Kedua sampel memiliki ragam yang homogen

H1: Kedua sampel tidak memiliki ragam yang homogen

\section{PENGUJIAN HIPOTESIS 2}

Pengujian statistik untuk hipotesis 2 dalam penelitian ini menggunakan uji-t berpasangan, yang dilakukan untuk mengestimasi rata-rata populasi dengan menggunakan sampel kecil pada populasi yang terdistribusi normal. Asumsi yang digunakan dalam pengujian ini adalah sebagai berikut (Santoso, 2004):

- Data bertipe kuantitatif, baik itu interval maupun rasio

- Data berdistribusi normal

- Data sampel berjumlah sedikit

Pengujian terhadap abnormal return mempunyai tujuan untuk melihat signifikansi abnormal return yang ada di periode peristiwa. Signifikansi tersebut untuk menentukan apakah abnormal return secara statistik signifikan tidak sama dengan nol dan menggunakan uji-t ( $t$-test), dengan ketentuan (Jogiyanto, 2000):

a. Jika t-hitung $>1.638$ signifikan pada tingkat $10 \%$.

b. Jika t-hitung $>2.353$ signifikan pada tingkat $5 \%$.

c. Jika t-hitung $>4.541$ signifikan pada tingkat $1 \%$

\section{HASIL PENELITIAN DAN PEMBAHASAN}

Hasil Uji Normalitas 
Untuk menguji apakah sampel penelitian berdistribusi normal, maka digunakan pengujian Kolmogorov Smirnov Test terhadap masing-masing variabel dengan $\alpha=$ 5\%.Hipotesispengujianyaitu:

H0: Data menyebar normal

H1: Data tidak menyebar normal

Kriteria pengujian menyatakan jika probabilitas hitung >level of significance $(\alpha)$ maka data dikatakan berdistribusi normal.Hasil pengujian uji normalitas tercantum dalam lampiran 1, dimana hasil pengujian untuk seluruh periode 2007-2012 menunjukkan probabilitas hitung pada AAR sebelum dan sesudah 1 Januari >level of significance $(\alpha=5 \%)$, begitu pula dengan probabilitas hitung ACAR saham kapitalisasi besar dan kecil>level of significance $(\alpha=5 \%)$. Hal ini berarti data berdistribusi normal. Dengan demikian, asumsi normalitas terpenuhi sehinggadapat dilakukannya parametric-test dan data tersebut dianggap bisa mewakili populasi.

\section{HASIL PENGUJIAN HIPOTESIS}

\section{H1: Terdapat Perbedaan Nilai Average Abnormal Return (Aar) Sebelum Dan Sesudah Tanggal 1 Januari}

Sebelum melakukan uji signifikansi t independen, maka perlu dilakukan pengujian kehomogenan ragam 2 sampel tersebut. Pengujian digunakan untuk mengetahui apakah 2 sampel tersebut memiliki ragam yang homogen (konstan) atau tidak. Untuk menguji apakah 2 sampel penelitian memiliki ragam yang homogen, maka digunakan pengujian ratio 2 ragam terhadap masing-masing sampel dengan $\alpha=5 \%$.Kriteria pengujian menyatakan jika probabilitas hitung >level of significance $(\alpha)$ maka 2 sampel tersebut dikatakan memiliki ragam yang homogen.Adapun hipotesispengujian adalah sebagai berikut:

H0: Kedua sampel memiliki ragam yang homogen

H1: Kedua sampel tidak memiliki ragam yang homogen

Hasil pengujian tersebut ditunjukkanpada Lampiran 3, dimana probabilitas hitung ( $p$-value) pada rasio AAR sebelum dan sesudah 1 Januari untuk seluruh periode adalah>level of significance $(\alpha=5 \%)$. Hal ini berarti kedua sampel dari masing-masing periode tersebut memiliki ragam yang homogen. 
Di bawah ini menampilkan hasil perhitungan Average Abnormal Return (AAR) untuk keseluruhan perusahaan sampel. Hasil pengujian dan pembahasan hipotesis satu pada masingmasing periode penelitian akan dijelaskan sebagai berikut:

\section{Periode 2007-2008}

\section{Hasil Perhitungan AAR}

\begin{tabular}{|l|l|}
\hline HARI & AAR \\
\hline H-3 & 0,003569928 \\
\hline H-2 & 0,005915361 \\
\hline H-1 & 0,014011429 \\
\hline H+1 & $-0,016458509$ \\
\hline H+2 & $-0,006712313$ \\
\hline H+3 & $-0,019936627$ \\
\hline
\end{tabular}

\section{Grafik Rata-Rata Abnormal Return}

Periode 2007-2008

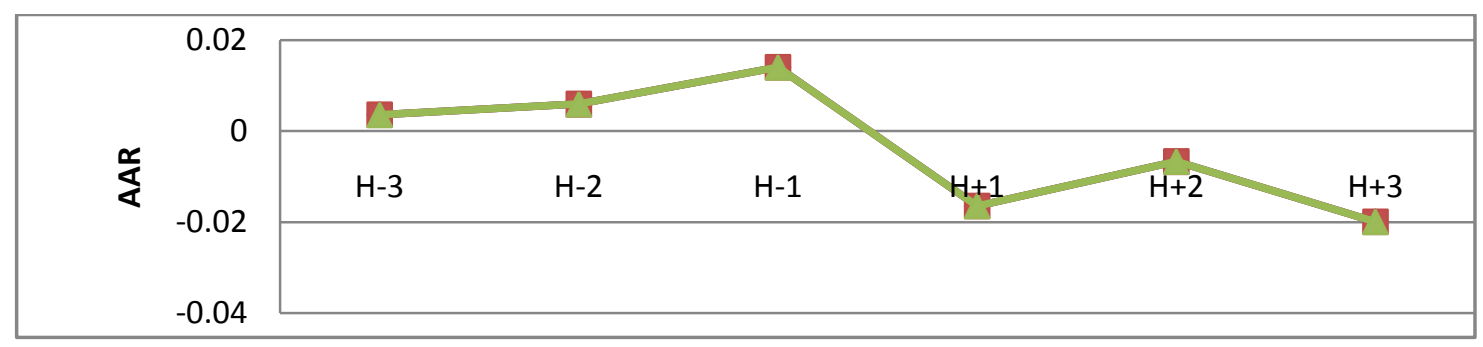

Dari Gambar diatas dapat terlihat bahwa abnormal return naik dari hari ke-3 (H-3) sebelum tanggal 1 Januari hingga 1 hari sebelum (H-1) tanggal 1 Januari. Kemudian, terjadi penurunan bahkan menunjukkan nilai negatif pada hari pertama setelah $(\mathrm{H}+1)$ tanggal 1 Januari, 2 hari setelah $(\mathrm{H}+2)$ tanggal 1 Januari abnormal return mulai naik tetapi masih bernilai negatif, dan kembali turun pada hari ke-3 setelah $(\mathrm{H}+3)$ tanggal 1 Januari. Hal ini menunjukkan bahwa tidak terdapat January Effect pada periode tahun 2007-2008.

Secara statistik, hal ini dapat dibuktikan dengan menggunakan Uji-t independen. Adapun ikhtisar output pengujian dapat dilihat pada tabel di bawah ini: 


\section{Hasil Pengujian Hipotesis 1 \\ Periode 2007-2008}

Secara umum, hipotesis dalam penelitian ini adalah

$\mathrm{H}_{0}$ : Tidak ada perbedaan rata-rata averageabnormal return(AAR) perusahaan yang terdaftar di Bursa Efek Indonesiapada periode sebelum dan sesudah tanggal 1 Januari 2008

$\mathrm{H}_{1}$ : Terdapat perbedaan rata-rata averageabnormal return(AAR) perusahaan yang terdaftar di Bursa Efek Indonesiapada periode sebelum dan sesudah tanggal 1 Januari 2008

Hasil pengujian menunjukkan bahwa probabilitas sebesar $0.168>$ alpha 5\% atau probabilitas (Sig.)>level of significance (alpha $(\alpha)=5 \%$ ), sehingga $\mathrm{H}_{0}$ diterima. Hal ini menunjukkan bahwa tidak terdapat perbedaan perbedaan rata-rata averageabnormal return (AAR) perusahaan yang terdaftar di Bursa Efek Indonesia pada periode sebelum dan sesudah tanggal 1 Januari 2008. Berdasarkan tabel diatas, pada periode 2007 - 2008 perusahaan yang terdaftar di Bursa Efek Indonesia memilki averageabnormal return (AAR) yang sama pada periode sebelum dan sesudah tanggal 1 Januari 2008.

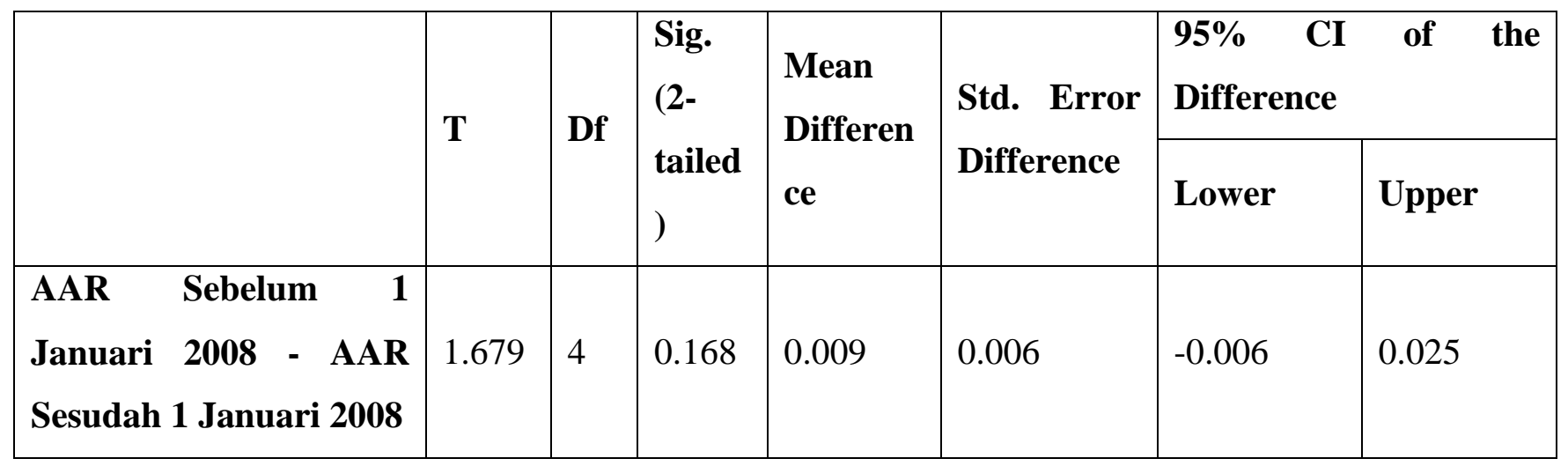

2. Periode 2008-2009

Hasil Perhitungan AAR

\begin{tabular}{|l|l|}
\hline HARI & AAR \\
\hline H-3 & $-0,0047137449$ \\
\hline H-2 & 0,00883526 \\
\hline H-1 & 0,010211294 \\
\hline
\end{tabular}




\begin{tabular}{|l|l|}
\hline $\mathrm{H}+1$ & 0,021051307 \\
\hline $\mathrm{H}+2$ & 0,009090092 \\
\hline $\mathrm{H}+3$ & $-0,00017844$ \\
\hline
\end{tabular}

\section{Grafik Rata-Rata Abnormal Return}

Periode 2008-2009

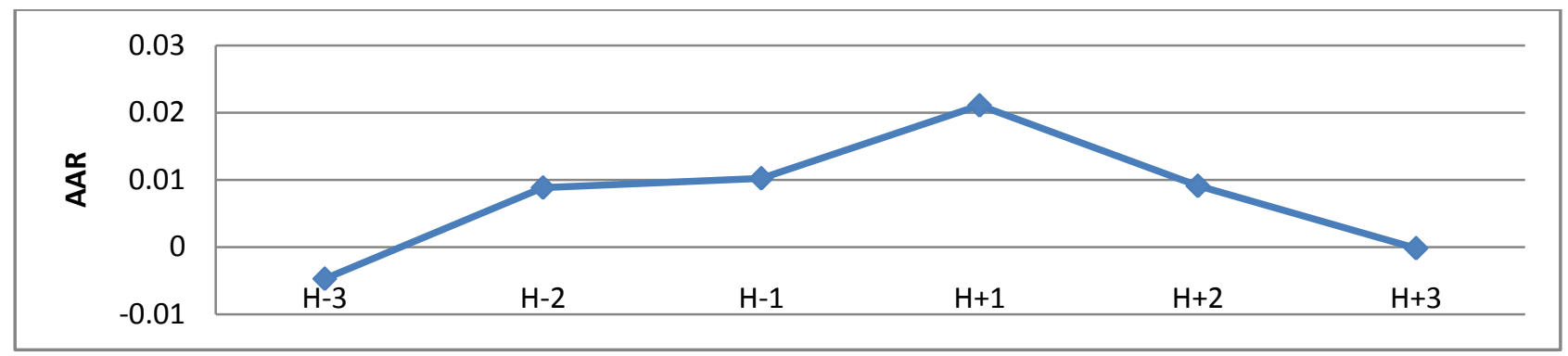

Dari Gambar di atas dapat terlihat bahwa abnormal return pada hari ke-3 sebelum (H-3) tanggal 1 Januari menunjukkan nilai negatif, namun merangkak naik pada hari ke-2 sebelum (H2) tanggal 1 Januari. Kemudian terus naik sampai H+1 tanggal 1 Januari. Abnormal return mulai mengalami penurunan pada hari ke-2 setelah $(\mathrm{H}+2)$ tanggal 1 Januari, da terus menurun hingga hari ke-3 setelah $(\mathrm{H}+3)$ tanggal 1 Januari. Hal ini menunjukkan bahwa terdapat January Effect dalam kurun waktu 1 hari setelah tanggal 1 Januari periode 2008-2009.

Namun, setelah dilakukan pengujian secara statistik menggunakan Uji-t Independen, maka diketahui tidak terdapat perbedaan rata-rata averageabnormal return (AAR) perusahaan yang terdaftar di Bursa Efek Indonesia pada periode sebelum dan sesudah tanggal 1 Januari 2009. Adapun ikhtisar output pengujian dapat dilihat pada tabel di bawah ini.

\section{Hasil Pengujian Hipotesis 1}

Periode 2008-2009

\begin{tabular}{|c|c|c|c|c|c|c|c|}
\hline & \multirow{2}{*}{$\mathbf{T}$} & \multirow{2}{*}{ Df } & \multirow{2}{*}{$\begin{array}{l}\text { Sig. } \\
(2- \\
\text { tailed } \\
)\end{array}$} & \multirow{2}{*}{$\begin{array}{l}\text { Mean } \\
\text { Differ } \\
\text { ence }\end{array}$} & \multirow{2}{*}{$\begin{array}{l}\text { Std. Error } \\
\text { Difference }\end{array}$} & \multicolumn{2}{|c|}{$\begin{array}{l}95 \% \text { CI of the } \\
\text { Difference }\end{array}$} \\
\hline & & & & & & Lower & Upper \\
\hline $\begin{array}{lrll}\text { AAR } & \text { Sebelum } 1 & \text { Januari } \\
2009 & - & \text { AAR } & \text { Sesudah } 1\end{array}$ & 1.808 & 4 & 0.145 & 0.016 & 0.009 & -0.009 & 0.041 \\
\hline
\end{tabular}




\begin{tabular}{|l|l|l|l|l|l|} 
Januari 2009 & & & & & \\
\hline
\end{tabular}

Secara umum, hipotesis dalam penelitian ini adalah

$\mathrm{H}_{0}$ : Tidak ada perbedaan rata-rata averageabnormal return(AAR) perusahaan yang terdaftar di Bursa Efek Indonesiapada periode sebelum dan sesudah tanggal 1 Januari 2009

$\mathrm{H}_{1}$ : Terdapat perbedaan rata-rata averageabnormal return(AAR) perusahaan yang terdaftar di Bursa Efek Indonesiapada periode sebelum dan sesudah tanggal 1 Januari 2009

Hasil pengujian menunjukkan bahwa probabilitas sebesar $0.145>$ alpha $5 \%$ atau probabilitas (Sig.)>level of significance (alpha $(\alpha)=5 \%$ ), sehingga $\mathrm{H}_{0}$ diterima. Hal ini menunjukkan bahwa tidak terdapat perbedaan perbedaan rata-rata averageabnormal return (AAR) perusahaan yang terdaftar di Bursa Efek Indonesia pada periode sebelum dan sesudah tanggal 1 Januari 2009. Berdasarkan tabel diatas, pada periode 2008 - 2009 perusahaan yang terdaftar di Bursa Efek Indonesia memilki rata-rata averageabnormal return (AAR) yang sama pada periode sebelum dan sesudah tanggal 1 Januari 2009.

\section{Periode 2009-2010}

\section{Hasil Perhitungan AAR}

\begin{tabular}{|l|l|}
\hline HARI & AAR \\
\hline H-3 & 0,008460328 \\
\hline H-2 & 0,011860746 \\
\hline H-1 & 0,004130464 \\
\hline H+1 & 0,003493552 \\
\hline H+2 & 0,010442815 \\
\hline H+3 & 0,001471237 \\
\hline
\end{tabular}

Grafik Rata-Rata Abnormal Return

Periode 2009-2010

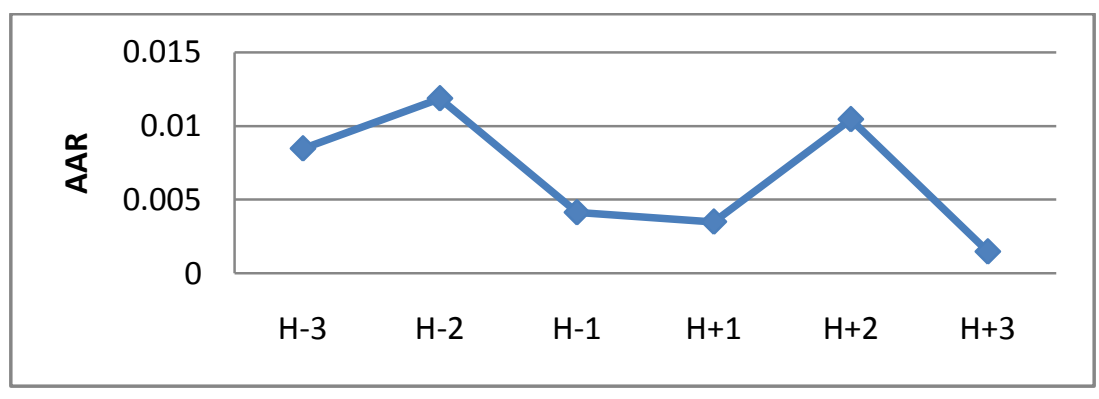


Dari Gambar diatas dapat terlihat bahwa abnormal return naik dari hari ke-3 (H-3) sebelum tanggal 1 Januari, kemudian terus menurun mulai 2 hari (H-2), hingga hari pertama setelah $(\mathrm{H}+1)$ tanggal 1 January. Abnormal return mulai naik pada hari ke-2 setelah $(\mathrm{H}+2)$ tanggal 1 Januari, namun kembali turun pada hari ke-3 $(\mathrm{H}+3)$. Hal ini dapat disimpulkan bahwa menunjukkan tidak terdapat reaksi pasar atas anomali January Effect pada periode tahun 20092010.

Pengujian secara statistik menggunakan Uji-t independen. Adapun ikhtisar output pengujian dapat dilihat pada tabel di bawah ini.

\section{Hasil Pengujian Hipotesis 1}

Periode 2009-2010

\begin{tabular}{|c|c|c|c|c|c|c|c|}
\hline & \multirow{2}{*}{$\mathbf{T}$} & \multirow{2}{*}{ df } & \multirow{2}{*}{$\begin{array}{l}\text { Sig. } \\
(2- \\
\text { taile } \\
\text { d) }\end{array}$} & \multirow{2}{*}{$\begin{array}{l}\text { Mean } \\
\text { Diffe } \\
\text { rence }\end{array}$} & \multirow{2}{*}{$\begin{array}{l}\text { Std. Error } \\
\text { Difference }\end{array}$} & \multicolumn{2}{|c|}{$\begin{array}{l}95 \% \text { CI of the } \\
\text { Difference }\end{array}$} \\
\hline & & & & & & Lower & Upper \\
\hline $\begin{array}{l}\text { AAR Sebelum } 1 \text { Januari } \\
2010 \text { - AAR Sesudah } 1 \\
\text { Januari } 2010\end{array}$ & -1.296 & 4 & 0.265 & 0.006 & 0.005 & -0.019 & 0.007 \\
\hline
\end{tabular}

Secara umum, hipotesis dalam penelitian ini adalah

$\mathrm{H}_{0}$ : Tidak ada perbedaan rata-rata averageabnormal return(AAR) perusahaan yang terdaftar di

Bursa Efek Indonesiapada periode sebelum dan sesudah tanggal 1 Januari 2010

$\mathrm{H}_{1}$ : Terdapat perbedaan rata-rata averageabnormal return(AAR) perusahaan yang terdaftar di

Bursa Efek Indonesiapada periode sebelum dan sesudah tanggal 1 Januari 2010

Hasil pengujian menunjukkan bahwa probabilitas sebesar $0.265>$ alpha $5 \%$ atau probabilitas (Sig.)>level of significance (alpha $(\alpha)=5 \%$ ), sehingga $\mathrm{H}_{0}$ diterima. Hal ini menunjukkan bahwa tidak terdapat perbedaan rata-rata averageabnormal return (AAR) perusahaan yang terdaftar di Bursa Efek Indonesia pada periode sebelum dan sesudah tanggal 1 Januari 2010. Berdasarkan tabel di atas, pada periode 2009 - 2010 perusahaan yang terdaftar di Bursa Efek Indonesia memilki rata-rata averageabnormal return (AAR) yang sama pada periode sebelum dan sesudah tanggal 1 Januari 2010. 


\section{Periode 2010-2011}

\section{Hasil Perhitungan AAR}

\begin{tabular}{|l|l|}
\hline HARI & AAR \\
\hline H-3 & 0,004184652 \\
\hline H-2 & 0,015232335 \\
\hline H-1 & 0,006753924 \\
\hline H+1 & 0,000684429 \\
\hline H+2 & $-0,006389593$ \\
\hline H+3 & 0,002370074 \\
\hline
\end{tabular}

\section{Grafik Rata-Rata Abnormal Return}

Periode 2010-2011

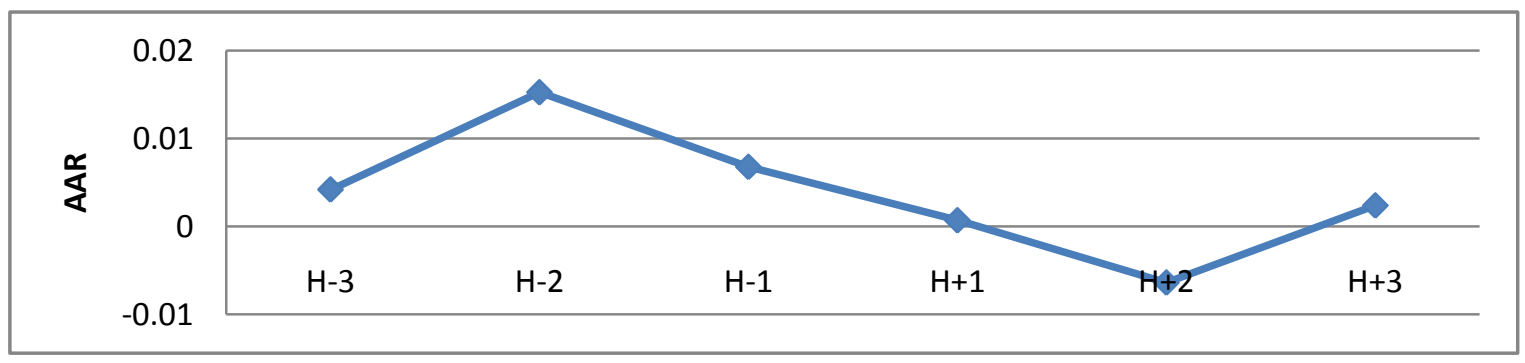

Dari Gambar diatas dapat terlihat bahwa abnormal return naik dari hari ke-3 (H-3) sebelum tanggal 1 Januari hingga hari ke-2 sebelum 1 Januari. Kemudian terus menurun bahkan menunjukkan nilai negatif mulai 2 hari (H-2) sampai hari ke-2 (H+2) setelah tanggal 1 Januari, abnormal return mulai naik dan menunjukkan nilai positif ditunjukkan pada hari ke-3 setelah tanggal 1 Januari. Hal ini menunjukkan bahwa tidak terdapat January Effect pada periode 20102011.Hal ini diperkuat dengan pengujian secara statistik dengan menggunakan uji-t independen. Adapun ikhtisar output pengujian dapat dilihat pada tabel di bawah ini.

\section{Hasil Pengujian Hipotesis 1}

Periode 2010-2011

\begin{tabular}{|l|l|l|l|l|l|l|l|}
\hline & T & Df & $\begin{array}{l}\text { Sig. (2- } \\
\text { tailed) }\end{array}$ & $\begin{array}{l}\text { Mea } \\
\text { n }\end{array}$ & Stdfe Error & S5\% CI of the & Difference \\
\cline { 5 - 7 } & & & Difference & Lower & Upper \\
\hline
\end{tabular}




\begin{tabular}{|c|c|c|c|c|c|c|c|}
\hline & & & & e & & & \\
\hline $\begin{array}{l}\text { AAR Sebelum } 1 \text { Januari } \\
2011 \text { - AAR Sesudah } 1 \\
\text { Januari } 2011\end{array}$ & -0.581 & 4 & 0.592 & $\begin{array}{l}- \\
0.005\end{array}$ & 0.009 & -0.030 & 0.020 \\
\hline
\end{tabular}

Secara umum, hipotesis dalam penelitian ini adalah

$\mathrm{H}_{0}$ : Tidak ada perbedaan rata-rata averageabnormal return(AAR) perusahaan yang terdaftar di

Bursa Efek Indonesiapada periode sebelum dan sesudah tanggal 1 Januari 2011

$\mathrm{H}_{1}$ : Terdapat perbedaan rata-rata averageabnormal return(AAR) perusahaan yang terdaftar di

Bursa Efek Indonesiapada periode sebelum dan sesudah tanggal 1 Januari 2011

Hasil pengujian menunjukkan bahwa probabilitas sebesar $0.592>$ alpha 5\% atau probabilitas (Sig.)>level of significance (alpha $(\alpha)=5 \%$ ), sehingga $\mathrm{H}_{0}$ diterima. Hal ini menunjukkan bahwa tidak terdapat perbedaan perbedaan rata-rata averageabnormal return (AAR) perusahaan yang terdaftar di Bursa Efek Indonesia pada periode sebelum dan sesudah tanggal 1 Januari 2011. Berdasarkan tabel diatas, pada periode 2010 - 2011 perusahaan yang terdaftar di Bursa Efek Indonesia memilki rata-rata averageabnormal return (AAR) yang sama pada periode sebelum dan sesudah tanggal 1 Januari 2011.

\section{Periode 2011-2012}

\section{Hasil Perhitungan AAR}

\begin{tabular}{|l|l|}
\hline HARI & AAR \\
\hline H-3 & 0,002603818 \\
\hline H-2 & 0,006013789 \\
\hline H-1 & $-0,026744706$ \\
\hline H+1 & 0,016547554 \\
\hline H+2 & 0,005546976 \\
\hline H+3 & $-0,006668525$ \\
\hline
\end{tabular}




\section{Grafik Rata-Rata Abnormal Return}

Periode 2011-2012

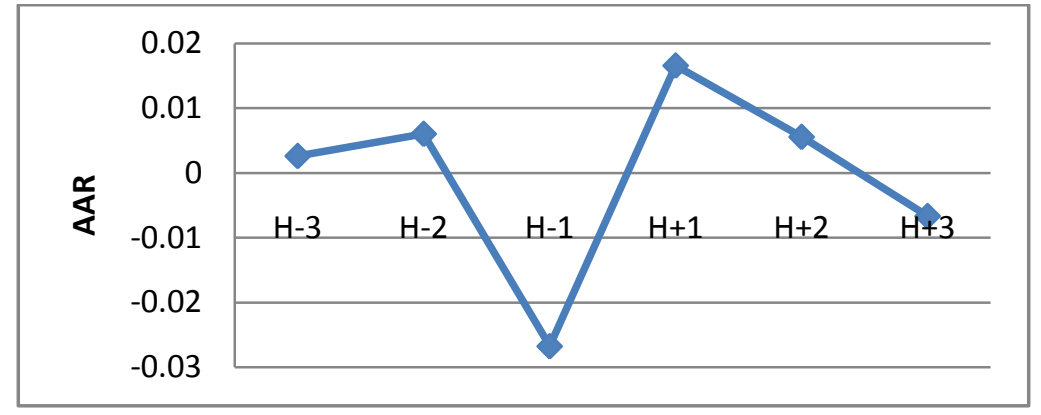

Dari Gambar diatas dapat terlihat bahwa abnormal return naik dari hari ke-3 (H-3) sebelum tanggal 1 Januari hingga hari ke-2 sebelum 1 Januari. Kemudian terus menurun bahkan menunjukkan nilai negatif mulai 2 hari (H-2) sampai $\mathrm{H}-1$ tanggal 1 Januari. Abnormal return menunjukkan peningkatan dan nilai positif dapat dilihat pada hari pertama setelah $(\mathrm{H}+1)$ tanggal 1 Januari, dan kemudian kembali menurun dan menunjukkan nilai negatif pada hari ke-3 setelah $(\mathrm{H}+3)$ tanggal 1 Januari. Hal ini menunjukkan bahwa terdapat January Effect dalam kurun waktu 1 hari setelah tanggal 1 Januari.

Namun, meskipun bila dilihat dari perbedaan Average Abnormal Return (AAR) terdapat January Effect, perbedaan tersebut tidak signifikan secara statistik. Hasil pengujian statistik didapatkan hasil temuan yang berbeda dari penelitian ini melalui Uji-t independen. Adapun ikhtisar output pengujian dapat dilihat pada tabel di bawah ini.

\section{Hasil Pengujian Hipotesis 1}

Periode 2011-2012

\begin{tabular}{|c|c|c|c|c|c|c|c|}
\hline & \multirow{2}{*}{$\mathbf{T}$} & \multirow{2}{*}{ df } & \multirow{2}{*}{$\begin{array}{l}\text { Sig. } \\
(2- \\
\text { tailed } \\
)\end{array}$} & \multirow{2}{*}{$\begin{array}{l}\text { Mean } \\
\text { Differ } \\
\text { ence }\end{array}$} & \multirow{2}{*}{$\begin{array}{l}\text { Std. } \\
\text { Error } \\
\text { Differen } \\
\text { ce }\end{array}$} & \multicolumn{2}{|c|}{$\begin{array}{l}95 \% \text { CI of the } \\
\text { Difference }\end{array}$} \\
\hline & & & & & & Lower & Upper \\
\hline $\begin{array}{l}\text { AAR Sebelum } 1 \text { Januari } \\
2012 \text { - AAR Sesudah } 1 \\
\text { Januari } 2012\end{array}$ & 0.480 & 4 & 0.656 & 0.002 & 0.005 & -0.010 & 0.015 \\
\hline
\end{tabular}

Secara umum, hipotesis dalam penelitian ini adalah 
$\mathrm{H}_{0}$ : Tidak ada perbedaan rata-rata averageabnormal return(AAR) perusahaan yang terdaftar di Bursa Efek Indonesiapada periode sebelum dan sesudah tanggal 1 Januari 2012 $\mathrm{H}_{1}$ : Terdapat perbedaan rata-rata averageabnormal return(AAR) perusahaan yang terdaftar di

Bursa Efek Indonesiapada periode sebelum dan sesudah tanggal 1 Januari 2012

Dari tabel 5.10 didapatkan hasil pengujian yang menunjukkan bahwa probabilitas sebesar 0. $656>$ alpha $5 \%$ atau probabilitas (Sig.) >level of significance (alpha $(\alpha)=5 \%$ ), sehingga $\mathrm{H}_{0}$ diterima. Hal ini menunjukkan bahwa tidak terdapat perbedaan perbedaan rata-rata averageabnormal return (AAR) perusahaan yang terdaftar di Bursa Efek Indonesia pada periode sebelum dan sesudah tanggal 1 Januari 2012. Berdasarkan tabel diatas, pada periode 2011 - 2012 perusahaan yang terdaftar di Bursa Efek Indonesia memilki rata-rata averageabnormal return (AAR) yang sama pada periode sebelum dan sesudah tanggal 1 Januari 2012.

\section{Periode 2012-2013}

\section{Hasil Perhitungan AAR}

\begin{tabular}{|l|l|}
\hline HARI & AAR \\
\hline H-3 & 0,005290651 \\
\hline H-2 & 0,007195637 \\
\hline H-1 & 0,017185026 \\
\hline H+1 & 0,028476743 \\
\hline H+2 & 0,019122484 \\
\hline H+3 & 0,014680945 \\
\hline
\end{tabular}

\section{Grafik Rata-Rata Abnormal Return}

Periode 2012-2013

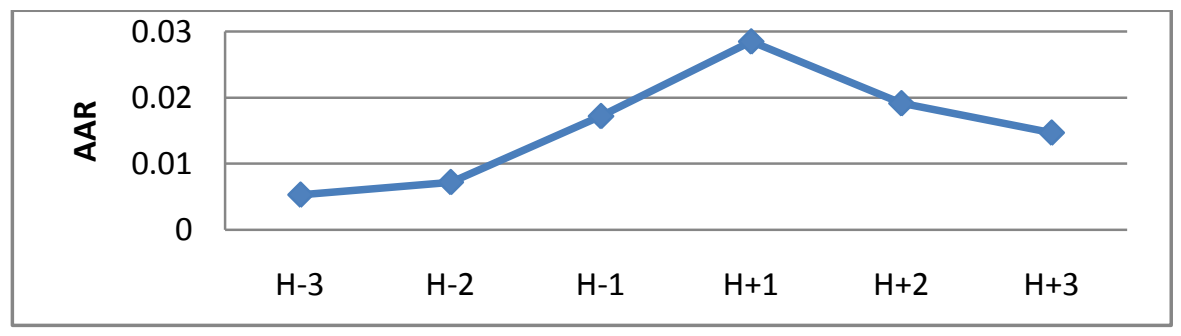

Dari Gambar diatas dapat terlihat bahwa abnormal return naik dari hari ke-3 (H-3) sebelum tanggal 1 Januari hingga hari ke-2 sebelum 1 Januari. Bahkan nilai AAR terus naik hingga $\mathrm{H}+1$ tanggal 1 Januari. AAR mulai turun pada hari ke-2 setelah $(\mathrm{H}+2)$ tanggal 1 Januari, 
dan terus menurun hingga hari ke-3 setelah $(\mathrm{H}+3)$ setelah tanggal 1 Januari. Jika dilihat dari hasil AAR diatas dapat disimpulkan bahwa terdapat reaksi pasar ata anomali January Effect pada periode tahun 2012-2013.

Namun, meskipun bila dilihat dari perbedaan Average Abnormal Return (AAR) terdapat January Effect, perbedaan tersebut tidak signifikan secara statistik. Hal tersebut dibuktikan melalui pengujian statistik dengan menggunakan Uji-t independen. Adapun ikhtisar output pengujian dapat dilihat pada tabel di bawah ini.

\section{Hasil Pengujian Hipotesis 1}

Periode 2012-2013

\begin{tabular}{|c|c|c|c|c|c|c|c|}
\hline & \multirow{2}{*}{$\mathbf{t}$} & \multirow{2}{*}{ Df } & \multirow{2}{*}{$\begin{array}{l}\text { Sig. } \\
(2- \\
\text { tailed } \\
\text { ) }\end{array}$} & \multirow{2}{*}{$\begin{array}{l}\text { Mean } \\
\text { Differ } \\
\text { ence }\end{array}$} & \multirow{2}{*}{$\begin{array}{l}\text { Std. Error } \\
\text { Difference }\end{array}$} & \multicolumn{2}{|c|}{$\begin{array}{l}95 \% \text { CI of the } \\
\text { Difference }\end{array}$} \\
\hline & & & & & & Lower & Upper \\
\hline $\begin{array}{l}\text { AAR Sebelum } 1 \text { Januari } \\
2013 \text { - AAR } \\
\text { Januari } 2013\end{array}$ & 0.992 & 4 & 0.378 & 0.004 & 0.004 & -0.008 & 0.016 \\
\hline
\end{tabular}

Secara umum, hipotesis dalam penelitian ini adalah

$\mathrm{H}_{0}$ : Tidak ada perbedaan rata-rata averageabnormal return(AAR) perusahaan yang terdaftar di

Bursa Efek Indonesiapada periode sebelum dan sesudah tanggal 1 Januari 2013

$\mathrm{H}_{1}$ : Terdapat perbedaan rata-rata averageabnormal return(AAR) perusahaan yang terdaftar di

Bursa Efek Indonesiapada periode sebelum dan sesudah tanggal 1 Januari 2013

Hasil pengujian menunjukkan bahwa probabilitas sebesar $0.378>$ alpha $5 \%$ atau probabilitas (Sig.)>level of significance (alpha $(\alpha)=5 \%$ ), sehingga $\mathrm{H}_{0}$ diterima. Hal ini menunjukkan bahwa tidak terdapat perbedaan perbedaan rata-rata averageabnormal return (AAR) perusahaan yang terdaftar di Bursa Efek Indonesia pada periode sebelum dan sesudah tanggal 1 Januari 2013. Berdasarkan tabel diatas, pada periode 2012 - 2013 perusahaan yang terdaftar di Bursa Efek Indonesia memilki rata-rata averageabnormal return (AAR) yang sama pada periode sebelum dan sesudah tanggal 1 Januari 2013. 


\section{H2: Terdapat perbedaan Average Cumulative Abnormal Return (ACAR) antara saham kapitalisasi kecil dengan saham kapitalisasi besar pada Bulan Januari.}

Pengujian hipotesis 2 penelitian ini dilakukan untuk mengetahui apakah terdapat perbedaan Average Cumulative Abnormal Return (ACAR) pada saham kapitalisasi kecil dengan saham kapitalisasi besar pada Bulan Januari. Dari tabel di bawah ini dapat dilihat bahwa terdapat perbedaan ACAR saham perusahaan kapitalisasi kecil dengan saham kapitalisasi besar pada Bulan Januari.

\section{Hasil Perhitungan ACAR}

\begin{tabular}{|l|l|l|}
\hline & $\begin{array}{l}\text { KAPITALISASI } \\
\text { BESAR }\end{array}$ & $\begin{array}{l}\text { KAPITALISASI } \\
\text { KECIL }\end{array}$ \\
\hline 2007 & $-0,01199$ & 0,026106 \\
\hline 2008 & $-0,0974$ & $-0,10371$ \\
\hline 2009 & $-0,033596$ & $-0,07775$ \\
\hline 2010 & 0,027436 & 0,030211 \\
\hline 2011 & $-0,07099$ & $-0,01288$ \\
\hline 2012 & 0,012299 & 0,10278 \\
\hline
\end{tabular}

Semua saham dengan kapitalisasi kecil pada seluruh periode kecuali hasil perhitungan ACAR tahun 2009, memiliki return yang lebih besar dibandingkan dengan saham kapitalisasi besar, hal ini mendukung penelitian yang telah dilakukan oleh Banz (1981) dimana dalam penelitiannya disimpulkan bahwa perusahaan dengan kapitalisasi pasar besar mempunyai return lebih kecil dibandingkan perusahaan kapitalisasi pasar kecil. Serta penelitian yang dilakukan oleh Lamoureux dan Sanger (1989), yang menyatakan bahwa semakin besar ukuran perusahaan, maka semakin kecil abnormal return-nya, dan perusahaan kecil cenderung memiliki abnormal return positif pada Bulan Januari.

Namun, pengujian secara statistik dengan menggunakan uji-t berpasangan yang dimaksudkan untuk mengetahui ada tidaknya perbedaan rata-rata kumulatif abnormal return (ACAR) pada saham kapitalisasi kecil dengan saham kapitalisasi besar pada Bulan Januari memperlihatkan hasil yang berbeda. Adapun ikhtisar output pengujian dapat dilihat pada tabel di bawah ini. 


\section{Hasil Pengujian Hipotesis 2}

\begin{tabular}{|c|c|c|c|c|c|c|c|c|}
\hline & \multicolumn{5}{|c|}{ Paired Differences } & \multirow{4}{*}{$\mathrm{T}$} & \multirow{4}{*}{ Df } & \multirow{4}{*}{$\begin{array}{l}\text { Sig. (2- } \\
\text { tailed) }\end{array}$} \\
\hline & \multirow{3}{*}{ Mean } & \multirow{3}{*}{$\begin{array}{l}\text { Std. } \\
\text { Deviatio } \\
\mathrm{n}\end{array}$} & \multirow{3}{*}{$\begin{array}{l}\text { Std. Error } \\
\text { Mean }\end{array}$} & \multirow{2}{*}{\multicolumn{2}{|c|}{$\begin{array}{l}95 \% \text { Confidence } \\
\text { Interval of the } \\
\text { Difference }\end{array}$}} & & & \\
\hline & & & & & & & & \\
\hline & & & & $\begin{array}{l}\text { Lowe } \\
\mathrm{r}\end{array}$ & Upper & & & \\
\hline $\begin{array}{l}\text { Saham Besar - } \\
\text { Saham } \\
\text { Kapitalisasi Kecil }\end{array}$ & -0.0231 & 0.0485 & 0.01982 & $\begin{array}{l}- \\
0.074 \\
1\end{array}$ & 0.0277 & $\begin{array}{l}- \\
1.169\end{array}$ & 32 & 0.295 \\
\hline
\end{tabular}

Secara umum, hipotesis dalam penelitian ini adalah

$\mathrm{H}_{0}$ : Tidak ada perbedaan rata-rata kumulatif abnormal return (ACAR) pada saham kapitalisasi kecil dengan saham kapitalisasi besar pada Bulan Januari

$\mathrm{H}_{1}$ : Terdapat perbedaan rata-rata kumulatif abnormal return (ACAR) pada saham kapitalisasi kecil dengan saham kapitalisasi besar pada Bulan Januari

Hasil pengujian menyatakan bahwa nilai statistik t pada Bulan Januari tersebut sebesar 1.169 dengan probabilitas (Sig.) sebesar 0.295. Kriteria pengujian menyebutkan apabila probabilitas hitung <level of significance (alpha $(\alpha)=5 \%)$ maka terdapat perbedaan antara perbedaan rata-rata kumulatif abnormal return (ACAR) pada saham kapitalisasi kecil dengan saham kapitalisasi besar pada Bulan Januari.

Hasil pengujian menunjukkan bahwa probabilitas sebesar $0.295<$ alpha 5\% atau probabilitas (Sig.)<level of significance (alpha $(\alpha)=5 \%$ ), sehingga $\mathrm{H}_{0}$ diterima. Hal ini menunjukkan bahwa tidak terdapat perbedaan rata-rata kumulatif abnormal return (ACAR) pada saham kapitalisasi kecil dengan saham kapitalisasi besar pada Bulan Januari. Berdasarkan tabel diatas, pada bulan Januarisaham kapitalisasi kecil dengan saham kapitalisasi besarmemiliki ratarata kumulatif abnormal return (ACAR) yang sama. 


\section{PEMBAHASAN}

\section{Tidak Terdapat Perbedaan Nilai Average Abnormal Return (AAR) Sebelum dan Sesudah}

Tanggal 1 Januari

Dari 6 periode pengamatan yang telah dilakukan diatas, dapat disimpulkan bahwa tidak terdapat January Effect selama periode 2007-2012 pada saham sektor perbankan, properti dan infrastruktur di Bursa Efek Indonesia (BEI). Tidak adanya January Effect yang ditandai dengan tidak adanya abnormal return selama periode pengamatan disebabkan oleh beberapa hal. Pertama, hal ini bisa terjadi dikarenakan adanya perbedaan budaya, dimana di negara-negara Amerika dan Eropa pada akhir tahun atau Bulan Desember terdapat beberapa perayaan yaitu Natal dan Tahun Baru. Hal ini menyebabkan banyak investor yang memutuskan untuk menghabiskan waktu Natal dan pergantian tahun dengan berlibur. Pada bulan tersebut mayoritas penduduknya merayakan Natal dan Tahun Baru secara besar-besaran sehingga dibutuhkan dana yang banyak. Investor cenderung menahan investasinya guna mencukupi kebutuhan tersebut atau bahkan menjual saham yang dimilikinya. Oleh karena itu, return cenderung turun pada akhir tahun.

Ketika bursa dibuka kembali awal tahun atau setelah tanggal 1 Januari, di sini investor kembali melanjutnya kegiatan investasinya dan bahkan membuat strategi baru, sehingga meningkatkan return di awal tahun. Karena di Indonesia penduduknya mayoritas muslim, maka euforia perayaan Natal dan Tahun Baru di Indonesia tidak seperti yang terjadi di Amerika maupun Eropa. Oleh karena itu, perilaku investornya pun juga berbeda dan aktifitas di lantai bursa berjalan dengan normal dan tidak terjadi January Effect.

Kedua, tahun pajak di Indonesia tidak terjadi pada akhir tahun, akan tetapi tahun pajak di Indonesia terjadi pada Bulan Maret.

Tidak Terdapat perbedaan Average Cumulative Abnormal Return (ACAR) antara saham kapitalisasi kecil dengan saham kapitalisasi besar pada Bulan Januari

Dari hasil pengujian dan analisis, maka dapat disimpulkan bahwa tidak terdapat Size Effect selama Bulan Januari periode 2007-2012 pada saham sektor perbankan, properti dan infrastruktur yang terdaftar di Bursa Efek Indonesia (BEI). Tidak adanya Size Effect dapat dikarenakan bahwa abnormal return yang diperoleh oleh masing-masing perusahaan tidak terpengaruh dari besar atau kecilnya ukuran (size) perusahaan. Ukuran perusahaan (size) tidak menjadi bahan pertimbangan investor untuk memutuskan membeli atau menjual suatu saham. 
Selain itu, keberadaan anomali Size Effect bisa saja tidak terjadi pada Bulan Januari, tetapi bisa saja terjadi pada bulan lain yang terpengaruh oleh event dan fenomena yang berbeda pula. Di Indonesia, tidak ditemukan keberadaan anomali Size Effect kemungkinan dikarenakan bahwa ukuran perusahaan tidak menjadi suatu hal yang istimewa yang dapat dijadikan pertimbangan investor dalam melakukan kegiatan investasinya.

\section{KESIMPULAN}

Penelitian ini menggunakan pendekatan event study untuk menguji apakah pasar bereaksi atas adanya anomali January Effect dan Size Effect. Reaksi pasar dapat dilihat dari nilai abnormal return yang diperoleh. Penelitian ini juga menguji perbedaan Average Abnormal Return (AAR) saham sebelum dan sesudah tanggal 1 Januari, sebagai definisi dari adanya January Effect. Selain itu, penelitian ini juga menguji perbedaan Average Cumulative Abnormal Return (ACAR) yang diperoleh dari perusahaan kapitalisasi besar dengan saham kapitalisasi kecil.

Setelah dilakukan pengujian dan pembahasan, maka dapat disimpulkan bahwa tidak terdapat perbedaan antara nilai AAR sebelum dan sesudah tanggal 1 Januari, sehingga dapat disimpulkan bahwa anomali January Effect tidak terjadi. Dalam penelitian ini, January Effect dapat dilihat tidak memberikan efek positif dengan adanya reaksi pasar terhadap anomali ini.

Hal ini tidak sesuai dengan penelitian-penelitian terdahulu yang selalu menemukan January Effect dalam penelitiannya. Tidak adanya January Effect yang ditandai dengan tidak adanya abnormal return selama periode pengamatan disebabkan oleh beberapa hal. Pertama, karena dikarenakan adanya perbedaan budaya, dimana pada negara maju pada akhir tahun atau bulan Desember terdapat beberapa perayaan yaitu Natal dan Tahun Baru. Pada bulan tersebut mayoritas penduduk merayakan hari tersebut secara besar-besaran sehingga dibutuhkan dana yang banyak. Investor cenderung menahan investasinya guna mencukupi kebutuhan tersebut atau bahkan menjual saham yang dimilikinya. Kedua, tahun pajak di Indonesia tidak terjadi pada akhir tahun, akan tetapi tahun pajak di Indonesia terjadi pada bulan Maret.

Begitu pula pada Hipotesis 2, setelah dilakukan pengujian hipotesis dan pembahasan yang menyatakan bahwa hasil penelitian adalah tidak terdapat perbedaan nilai ACAR antara saham kapitalisasi kecil dengan saham kapitaliasi besar pada Bulan Januari, sehingga dapat disimpulkan bahwa anomali Size Effect tidak terjadi. 
Tidak adanya Size Effect dapat dikarenakan bahwa abnormal return yang diperoleh oleh masing-masing perusahaan tidak terpengaruh dari besar atau kecilnya ukuran (size) perusahaan. Selain itu, keberadaan anomali Size Effect bisa saja tidak terjadi pada Bulan Januari, tetapi bisa saja terjadi pada bulan lain yang terpengaruh oleh event dan fenomena yang berbeda pula.

\section{DAFTAR PUSTAKA}

Ang, Robert. 2000. Buku Pintar Pasar Modal Indonesia (The Intelligent Guid to IndonesianCapital Market), Mediasoft Indonesia.

Belkoui,Ahmed Riahi. (2002).Teori Akuntansi. Salemba Empat, Jakarta

Binarto, Ikhsan. 2013. Saham Tiga Sektor Ini Paling Laku. http://bisnis.news.viva.co.id/news/read/361573

Christianto, Subur. 2010. "Reaksi Investor Saham LG-45 Terhadap Peristiwa Pemilu Di Bursa Efek Jakarta", Tesis, Program Pascasarjana Universitas Brawijaya Malang.

Chotigeat, Tosporn dan I.M. Pandey. 2005. "Seasonality In Asia's Emerging Markets:India and Malaysia.".Prosiding Internasional Trade and Finance Association.

Elton, Edwin J. dan Gruber, Martin J. 1995. Modern Portfolio Theory and Investment Analysis, Fifth Edition, John Wiley \& Sons, Inc.

Gumanti, Tatang Ary dan Elok Sri Utami. 2002. "Bentuk Pasar Efisien dan Pengujiannya", Jurnal Akuntansi \& Keuangan, Vol. 4, No.1, p54-66

Jogiyanto, Hartono M. 2000. Teori Portofolio dan Analisis Investasi, Edisi Ketiga PBFE. Yogyakarta

Jogiyanto, Hartono M. 2003. Metodologi Penelitian Bisnis: Salah Kaprah dan PengalamanPengalaman, Edisi 2004/2005, BPFE, Yogyakarta.

Pratomo, Agus Wahyu. 2007. January Effect dan Size Effec Pada Bursa Effect Jakarta (BEJ) Periode 1998-2005. Tesis. Program Studi Magister Manajemen Program Pascasarjana Universitas Diponegoro Semarang

Santoso, Singgih. 2004. SPSS Versi 10: Mengolah Data Statistik Secara Profesional, PT. Elex Media Komputindo, Jakarta

Sharpe, William F., Alexander, Gordon J., dan Bailey, Jeffrey V. 1995. Investments, Fifth Edition, Prentice Hall, New Jersey. 
Sucipto, Heri. 2012. "Uji Normalitas", http//sucipt0,blogspot.com/2012/11/uji-normalitas.html. Tendelin, Eduardus. 2001. "Analisis Investasi dan Manajemen Portofolio", Edisi 1, BPFEYogjakarta, Yogyakarta. 